$\mathbb{K}\left[\begin{array}{llllllll}\mathrm{R} & 0 & \mathbb{N} & \mathbb{N} & \mathbb{N} & E_{5} & \mathbb{N}\end{array}\right.$

Samfundsvidenskaber:

\title{
Politiske holdninger og ytringsfrihed
}

af Heine Andersen 
$\mathrm{E}$ t af de vigtigste erkendelsesmål i samfundsvidenskaberne, såvel som i andre videnskaber, har været at finde årsagslove. Der er flere grunde. Hvis vi kender årsagslove, kan vi bruge dem til at forklare og forudsige, hvad der sker. Hvis man kender årsagssammenhænge, kan man vide, hvad der virker i praksis. Så kan man styre og dermed opnå ønskede mål.

Men hvor sikker viden har vi om årsagslove, og hvor enige er vi? Hænger uenigheder sammen med politiske ideologier? Og hvor gode er vilkårene for, at uenighed, usikkerhed, fejltolkninger og misbrug kan diskuteres åbent? Her drejer det sig om forskernes ytringsfrihed. Det er de tre temaer, jeg vil tage op.

\section{Sikker viden om lovmæssigheder?}

Det første spørgsmål, har vi sikker viden om lovmæssigheder, har jeg valgt at belyse ved at bruge nogle resultater fra en interviewundersøgelse fra midten af 1990'erne. Der er tale om resultater fra et større projekt, som jeg lavede sammen med Bo Jacobsen, Finn Collin og Søren Barlebo med støtte fra Det Samfundsvidenskabelige Forskningsråd. Jeg stod for interviewundersøgelsen, som omfattede et repræsentativt udsnit af danske samfundsforskere, i alt 618, svarende til ca. 1/3 af alle (Andersen 1997, Andersen 1999). Svarprocenten var 90 pct. Det er altså den gruppe i Danmark, der burde vide mest om samfundsvidenskabernes resultater. Der er også det særlige ved undersøgelsen, at vi spurgte om forskernes politiske tilhørsforhold.

Som en del af undersøgelsen lavede vi en slags PISA-test af forskerne ved at spørge dem om, hvad samfundsforskningen viser vedrørende et antal udbredte påstande om lovmæssigheder. Spørgsmålet lød som følger: "Jeg præsenterer her nogle udsagn, som ofte indgår i den offentlige debat. Mener du forskningen kan give svar på disse spørgsmål? I givet fald, hvad mener du forskningen tyder mest på? At udsagnet er: 1) korrekt, 2) forkert, 3) forskning kan ikke give svar, 4) ved ikke om forskningen kan give svar. Jeg trækker kun tre af påstandene frem her. ${ }^{1}$ Den første lød: "En nedsættelse af mindstelønnen vil reducere arbejdsløsheden".

Spørgsmålet blev stillet i 1995 på et tidspunkt, hvor der faktisk stadig var høj arbejdsløshed. Som man kan se af figur 1, er der ikke just enighed. Næsten halvdelen - 45 pct. - sagde enten, at de ikke ved om forskningen kan give svar, eller at de ikke mener, at forskningen kan give svar. Blandt den resterende halvdel er der stor uenighed med en overvægt af forskere, der mener, at det vil reducere arbejdsløsheden. Men denne gruppe omfatter dog kun godt en tredjedel.

Nu kunne man tænke sig, at danske forskere dengang ikke var tilstrækkeligt opdaterede med internationale forskningsresultater. Her er det så heldigt, at der findes en frisk meningsmåling blandt amerikanske forskere, som drejer sig om næsten det samme, nemlig fra et ekspertpanel ved et af USAs førende universiteter, University of Chicago. Ekspertpanelet er sammensat af fremtrædende økonomiprofessorer fra hele USA, fra de førende universiteter og 


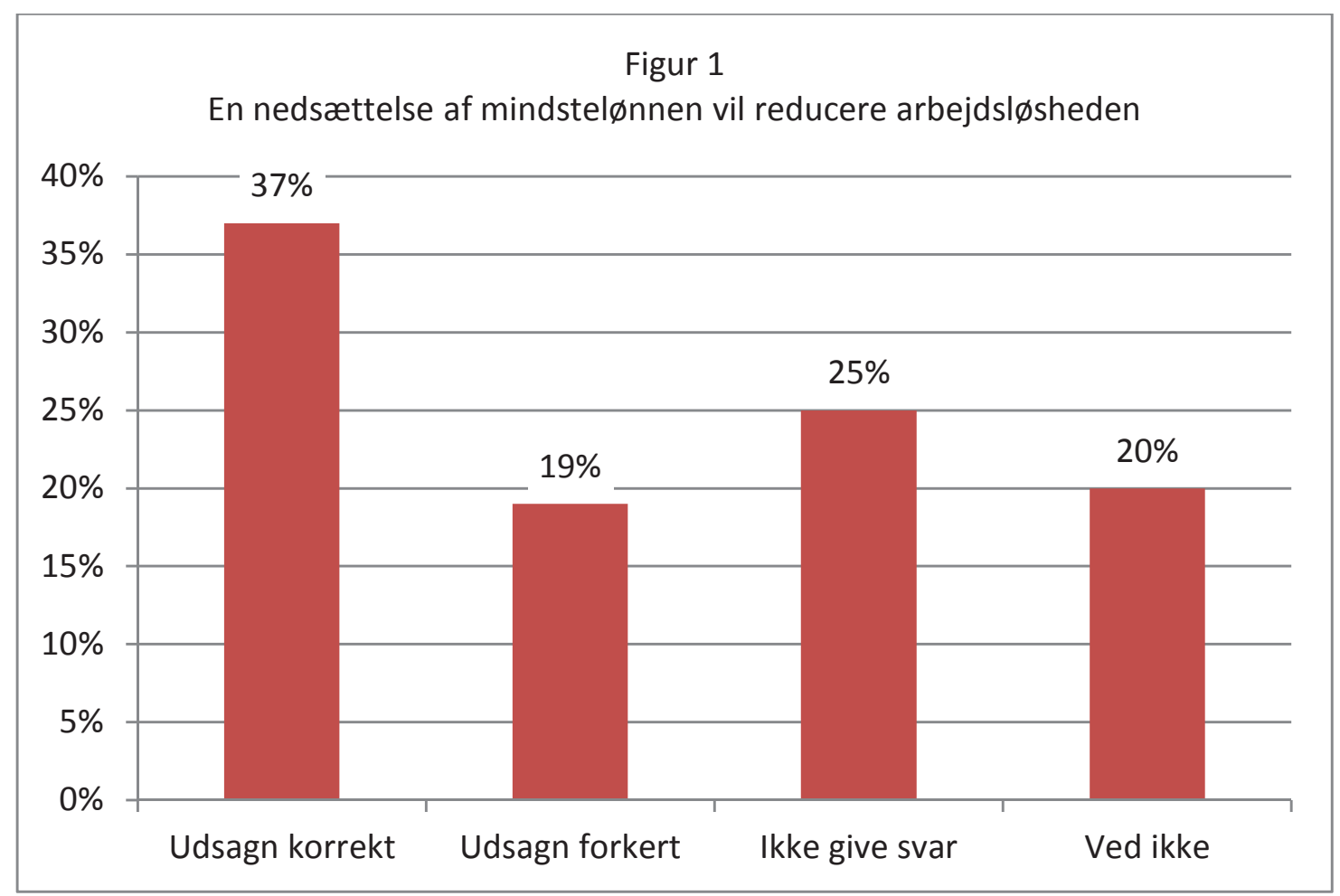

med poster i de mest prestigefyldte tidsskriftsredaktioner, som regeringsrådgivere osv. (se: Expert Panel, University of Chicago 2013, February).

Spørgsmålet, som de amerikanske økonomer er stillet overfor, er ikke enslydende med den danske undersøgelse, men dog tæt sammenligneligt (figur 2). Opgørelsen er også lavet lidt anderledes, men man kan se, at der er en

Figur 2

Raising the federal minimum wage to $\$ 9$ per hour would make it noticeably harder for low-skilled workers to find employment

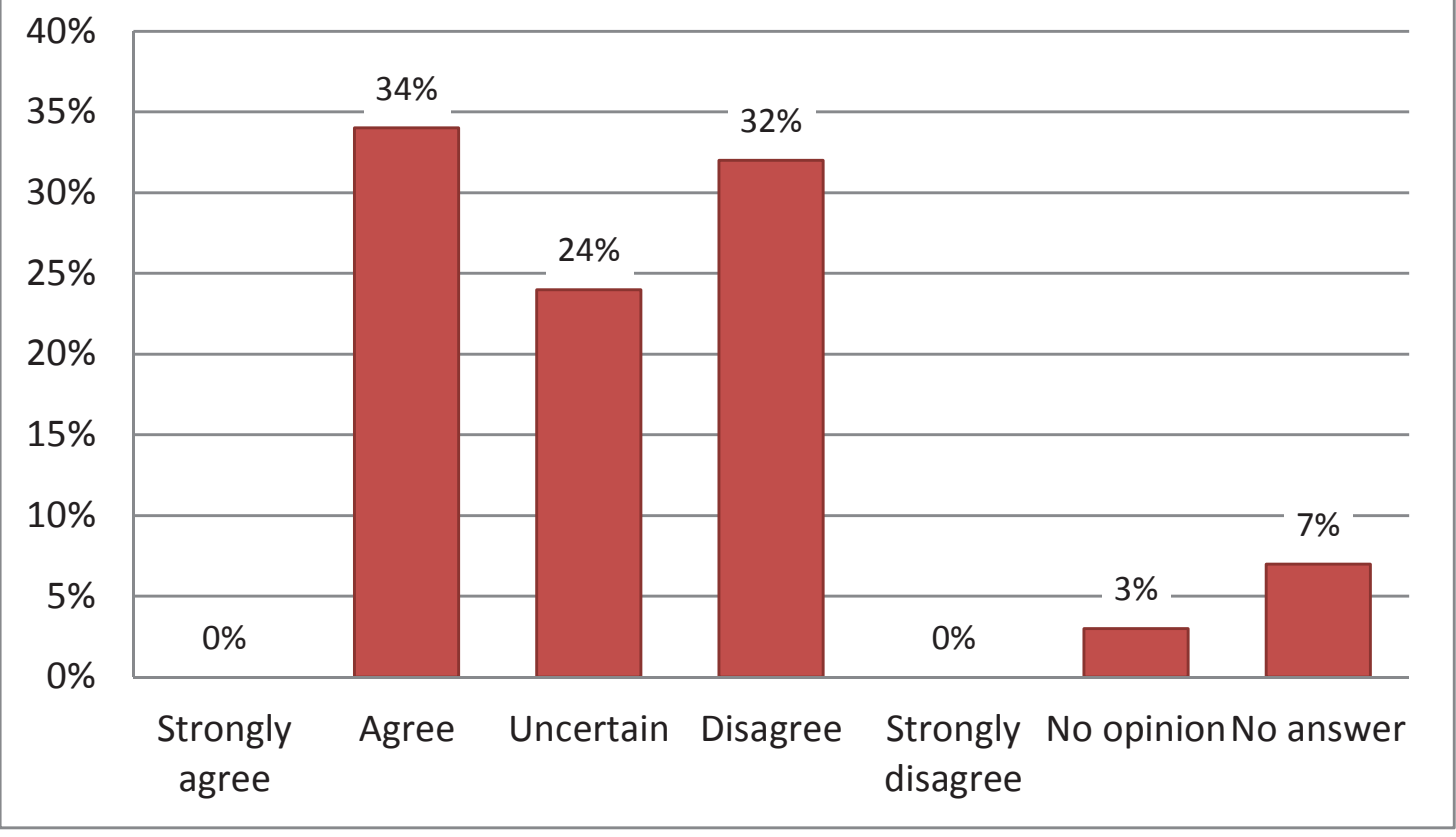


gruppe på 7 pct., der ikke har ønsket at svare, og en anden lille gruppe på 3 pct. der har svaret "no opinion". Dertil kommer en gruppe "uncertain" i midten i grafen på 24 pct. I alt er der altså 34 pct., der hverken mener det ene eller det andet. Resten, dem der har en mening, deler sig så i to næsten lige store grupper. Så meget klogere er vi ikke med hensyn til, hvordan ændringer i mindstelønnen virker på arbejdsløsheden.

Vi kan foreløbig konkludere, at der er stor usikkerhed med hensyn til, om der gælder nogen lovmæssighed her. Det er selvsagt klart, at det er vigtigt, at denne uenighed kommer åbent frem, både for at forskningen kan bringes videre, og hvis den skal bruges i praksis. En relevant videnskabsteoretisk opgave er at undersøge, om det sikres.

Næste påstand lød: "Medarbejderdemokrati øger produktiviteten". Arbejdsproduktivitet har også haft betydelig interesse og er blevet et aktuelt tema efter, at det har vist sig, at produktiviteten i Danmark halter bag efter så mange andre lande. For at få opklaret årsagerne har regeringen nedsat en produktivitetskommission. Hvad danske forskere mente i 1995, kan min undersøgelse kaste lys over. Der er mange faktorer, der kan påvirke produktiviteten, og en faktor er ledelsesformen, herunder graden af medarbejderdemokrati.

I dag støder man sjældent på glosen "medarbejderdemokrati", og hvis den dukker op, er det som regel med en rent negativ ladning. Men faktisk har man fundet former for demokrati i arbejdslivet, især fra 1970'erne og nogle år frem, som så er blevet udforsket bl.a. for at se, hvad det betød for produktiviteten.

Som man kan se af figur 3, lader det faktisk til, at enigheden her er noget større, end hvad angår det med mindstelønnen. Godt nok er der lige så mange, der melder pas (45 pct.), men til gengæld er der langt større enighed blandt dem, der mener at vide noget. Et meget stort flertal mener, at medar-

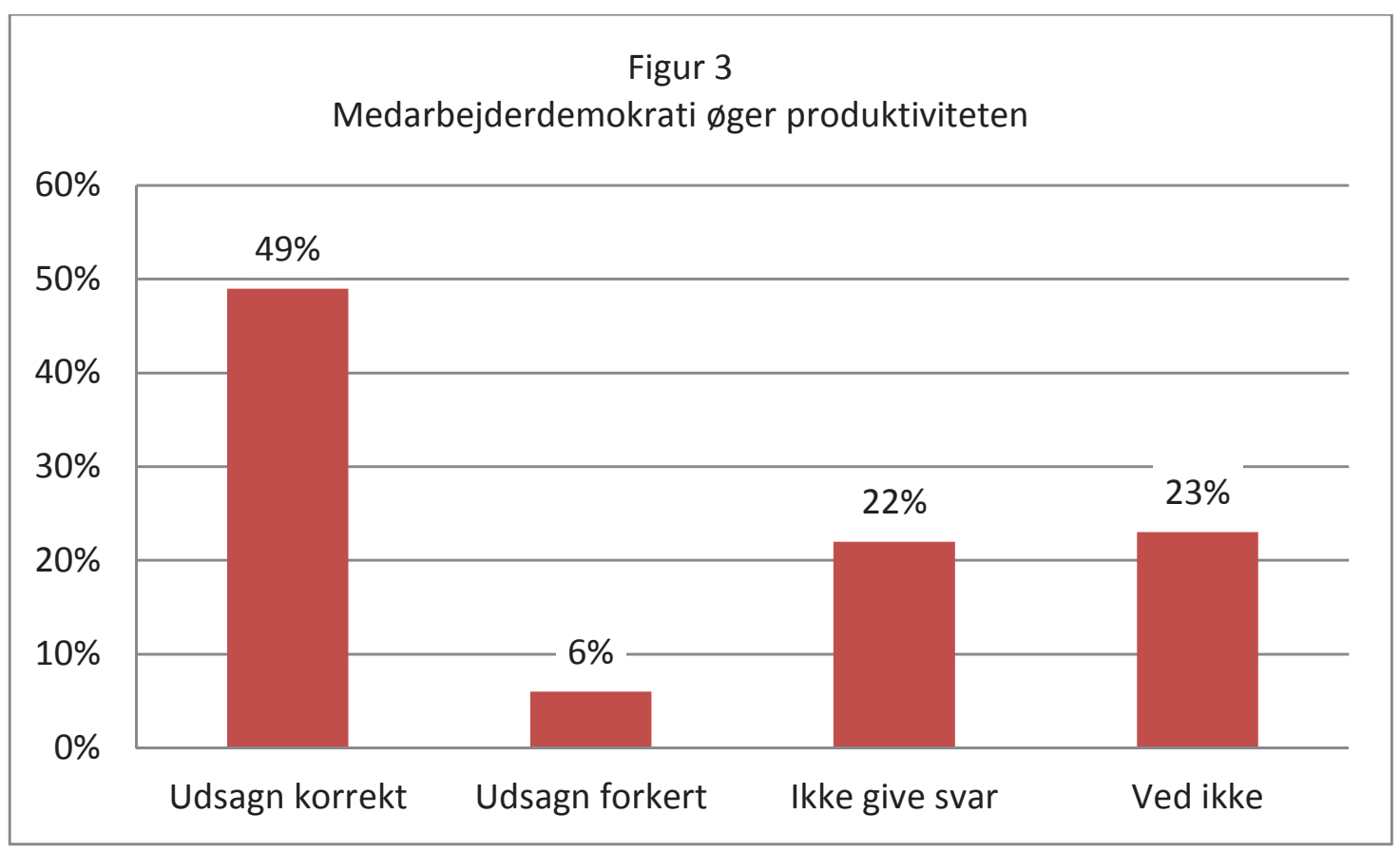


bejderdemokrati faktisk gavner produktiviteten. Det er dog stadig kun lige under halvdelen af samtlige forskere.

Desværre er der ikke tegn på, at produktivitetskommissionen vil tage denne viden med i sine analyser, og man kan blandt kommissionens medlemmer heller ikke umiddelbart få øje på nogen, der har særlig indsigt i spørgsmålet om ledelsesform. Et problem for videnskabsteori er at undersøge, hvilke videnstyper der inddrages, henholdsvis ekskluderes fra politiske processer.

Den tredje påstand lød: "Strengere straffe nedsætter kriminaliteten". Også her er der tale om et spørgsmål, der har været viet stor opmærksomhed meget længe. Ideen om at straf skal gøre nytte ved at reducere kriminalitet, dukkede frem i 1760'erne, og blev siden dominerende i kriminalpolitik. Straf skal virke. Derfor har der også været lagt mange kræfter i at undersøge, om den faktisk virker.

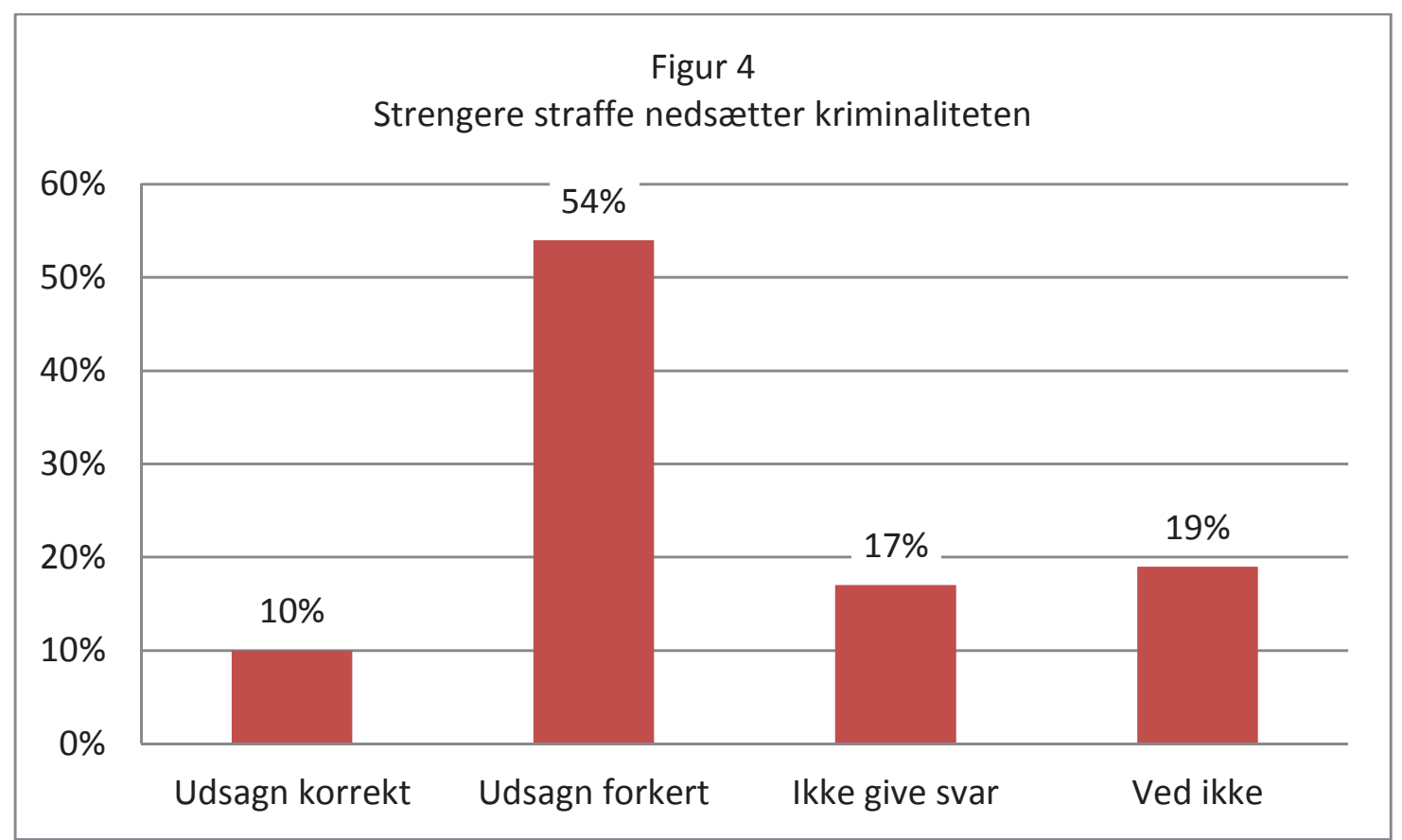

Her har vi faktisk et spørgsmål, hvor mere end halvdelen mener det samme (figur 4), nemlig et flertal på 54 pct., der mener, at udsagnet er forkert, altså at den påståede lovmæssighed ikke gælder. Dog er der stadig et mindretal på ca. 10 pct., der mener det modsatte. Og mere end en tredjedel melder pas på egne eller forskningens vegne. Svarene tyder mest på, at der ikke findes en sikker lovmæssig sammenhæng mellem straffens strenghed og kriminalitetsraten. Også her er det relevant at undersøge, hvordan denne viden udnyttes.

Alt i alt må man således sige, at disse eksempler på trods af mange års ihærdig forskningsindsats ikke demonstrerer oplagte kandidater til sikker viden om lovmæssigheder. Der kan være mange grunde til uenigheder og usikkerhed. Det kan være, at der simpelthen ikke findes årsagslove for det 
sociale, i hvert fald ikke af den omtalte type. Det er fortsat et åbent spørgsmål, om der nogensinde vil kunne findes eksempler på alment gældende årsagslove i samfundsvidenskaberne, dvs. lovmæssigheder der gælder uanset tid og sted. Spørgsmålet om, hvorvidt samfundsvidenskaberne kan og skal være lovmæssighedssøgende, nomotetiske videnskaber, har jo delt vandene fra starten. Det kan også være, at de findes, men at vi bare ikke har været gode nok til at finde og dokumentere dem. En tredje mulighed er, at de faktisk er fundet, men at nogle forskere af ikke-videnskabelige grunde nægter at anerkende dem. Det kan være, fordi det strider mod deres paradigmer eller politiske ideologier.

Her må videnskabsteorien forsøge at udrede forholdene. Jeg må nøjes med at behandle et enkelt aspekt, nemlig om uenigheden hænger sammen med politiske holdninger. Det er relevant at vide både for forskernes selvrefleksion og for de målgrupper, som eventuelt vil bruge forskningsresultaterne.

\section{Politiske holdninger og faglige vurderinger}

Spørgsmålet om forholdet mellem videnskabelige resultater på den ene side og holdninger og værdier på den anden er et klassisk tema i samfundsvidenskabernes videnskabsteori (Andersen 1999, Andersen 2003:107ff). På trods af det er der faktisk ikke foretaget andre repræsentative undersøgelser blandt forskere af emnet end den foreliggende. Vi spurgte forskerne, hvilket parti de havde stemt på ved folketingsvalget 1994, og i tabel 1 har jeg så delt forskerne op i to grupper, rød og blå blok. De radikale er her placeret i blå blok, og ellers er det den sædvanlige opdeling.

Med hensyn til påstanden om mindsteløn kan vi se, at der er en meget tydelig sammenhæng (tabel 1): i blå blok er andelen, der tror på effekten, tre gange så stor som i rød blok (61 pct. i blå blok mod 21 pct. i rød blok). Man kan også se, at der er langt større tiltro til, at forskningen kan give svar i blå blok end i rød blok.

Tabel 1. Politiske holdninger og faglige vurderinger

("Rød" = A + F+ Ø; "Blå" = B + D + C + V)

\begin{tabular}{lrrrrrr}
\hline Påstand: & \multicolumn{2}{l}{$\begin{array}{l}\text { Mindsteløn - } \\
\text { arbejdsløshed }\end{array}$} & \multicolumn{2}{c}{$\begin{array}{c}\text { Medarbejder- } \\
\text { demokrati - } \\
\text { produktivitet }\end{array}$} & $\begin{array}{c}\text { Strengere straffe - } \\
\text { nedsat kriminalitet }\end{array}$ \\
& Rød & Blå & Rød & Blå & Rød & Blå \\
\hline Parti, grupperet & $20 \%$ & $16 \%$ & $18 \%$ & $27 \%$ & $15 \%$ & $22 \%$ \\
\hline Ved ikke & $31 \%$ & $16 \%$ & $23 \%$ & $24 \%$ & $14 \%$ & $22 \%$ \\
\hline Kan ikke give svar & $29 \%$ & $8 \%$ & $4 \%$ & $8 \%$ & $66 \%$ & $39 \%$ \\
\hline Udsagn forkert & $21 \%$ & $61 \%$ & $55 \%$ & $42 \%$ & $5 \%$ & $16 \%$ \\
\hline Udsagn korrekt & $101 \%$ & $101 \%$ & $100 \%$ & $101 \%$ & $100 \%$ & $99 \%$ \\
\hline I alt & 299 & 211 & 299 & 211 & 299 & 211 \\
\hline N & & & & & & \\
\hline
\end{tabular}


Hvad angår påstanden, at medarbejderdemokrati øger produktiviteten, vil mange sikkert intuitivt forvente, at det er en "rød" forskeroverbevisning mere end en "blå". Denne forventede forskel er da også til stede, men ikke så markant, som tilfældet var med påstanden om mindsteløn. Også blå blok har klar overvægt for, at forskningen mest tyder på, at medarbejderdemokrati gavner produktiviteten.

Endelig med hensyn til det tredje spørgsmål, strengere straffe, kan vi igen se en ret tydelig sammenhæng: at strengere straffe skulle virke er et højrefløjsforskersynspunkt, men stadig er det dog kun et lille mindretal, der mener sådan (16 pct.). I rød blok er der næsten ingen, der mener, at forskningen skulle tyde på, at påstanden holder.

Der er altså meget tydelige sammenhænge mellem politisk ståsted og faglige overbevisninger, i nogle tilfælde med diametralt modsatte opfattelser til følge. Omverdenen kan få vidt forskellige svar, hvis man spørger samfundsforskere afhængigt af forskernes politiske standpunkt. Det er åbenlyst et alvorligt problem, metodologisk, forskningsetisk, forskningspolitisk såvel som demokratisk. En journalist spurgte, om man som konsekvens skulle forlange, at samfundsforskere deklarerer deres politiske standpunkt (jf. Myrdals forslag om, at forskere skal redegøre for deres værdier, Myrdal 1968:12f)? Man må af flere grunde afvise dette forslag, selvom det er relevant. Tre veje kan, om ikke løse problemet, så bidrage til at reducere skadevirkninger: 1) på alle niveauer: en pluralistisk forskningspolitik, så forskellige faglige retninger får ligeværdige vilkår og ingen får monopol; 2) blandt forskerne indbyrdes: et normsystem, der forpligter til en kritisk "organiseret skepticisme" (Merton 1969:614) og "videnskabsmændenes fjendtligt-venlige arbejdsdeling, deres samarbejde og deres modarbejden hinanden" (Popper 1962:240; se også Bredsdorff 2008 for en indsigtsfuld diskussion). Dette afhænger delvis af en hel række samfundsmæssige og politiske forhold, som gør denne kritik mulig, således at uenigheder blandt forskerne kommer åbent frem; 3) maksimal ytrings- og publiceringsfrihed.

I den sidste del vil jeg fremdrage fire eksempler, der især vedrører punkt tre. De viser alvorlige trusler mod forskningens publicerings- og ytringsfrihed.

\section{Forskningens ytrings- og publiceringsfrihed}

År 1600 blev Giordano Bruno brændt på bålet for at sige, at jorden ikke er universets centrum. År 1616 fik Galilei livsvarig husarrest og taleforbud for at sige, at jorden bevæger sig. Frigørelsesbevægelser inden for videnskaberne var dog på vej. Det var ikke på universiteterne, men ved dannelsen af de nye videnskabelige selskaber. I 1660'erne, på Robert Boyles og Newtons tid, gav den engelske kong Charles II det nystiftede Royal Society of London, det engelske videnskabsakademi, et Charter, hvor selskabet fik ret til at publicere deres tanker uden censur og ligeledes ret til at udveksle breve på tværs af græn- 
ser, mod at de til gengæld afholdt sig fra at blande sig i politik og religion (http://royalsociety.org/about-us/). Noget lignende skete i Frankrig. Dette var en forløber for den almindelige tanke- og ytringsfrihed, som blev indført med de demokratiske revolutioner - og i øvrigt også længe før det så ofte fejrede prøjsiske Humboldt Universitet. Princippet er bærende i oplysningstiden og i forestillingerne fra 1700-tallet om en forbindelse mellem viden, kritisk fornuft og frihed.

Dette er den bredere kulturelle og samfundsmæssige betydning af princippet. Der er også en intern metodologisk, funktionel begrundelse: publiceringsfrihed er nødvendig for videnskabelige fremskridt (Norges offentlige utredninger 2006:17-19). Det gælder i første omgang kontrolhensynet: inden resultater kan godtages, skal de granskes af andre for at se, om de er korrekte. Hvis der ikke er åben adgang til resultater, metoder og data, kan resultater ikke kontrolleres, og så kan de ikke godtages, jf. Mertons norm om "organiseret skepticisme" og Poppers idé om den "fjendtlig-venlige arbejdsdeling" omtalt ovenfor. Dernæst er publiceringsfrihed også en forudsætning for, at andre kan udnytte resultaterne, bruge dem i videre forskning og undgå at jagte resultater, som allerede er frembragt. Resultater er kollektiv ejendom. Merton kalder det normen om kommunisme (Merton 1969:610).

Princippet om forskningsfrihed, herunder publiceringsfrihed, har altså ganske solide historiske, kulturelle og værdimæssige rødder. Faktisk er det også sådan, at princippet er skrevet ind i grundloven i flere lande, eksempelvis i Finland og i Tyskland, ligesom det findes i en række internationale erklæringer og charters, bl.a. fra UNESCO, EU og Europarådet (Norges offentlige utredninger 2006:39-42).

For Danmarks vedkommende finder man princippet formuleret i Universitetslovens paragraf 2:

§ 2 Stk. 2. Universitetet har forskningsfrihed og skal værne om denne og om videnskabsetik.

Stk. 3. Universitetet skal som central viden- og kulturbærende institution udveksle viden og kompetencer med det omgivende samfund og tilskynde medarbejderne til at deltage i den offentlige debat.

Man kan se, at stk. 3 udgør en lidt afbleget formulering af universitetets rolle i forhold de klassiske oplysningsidealer, som jeg omtalte.

Den specificerede angivelse af, hvad forskningsfrihed omfatter, skal man finde i et regelsæt, som rektors "Praksisudvalg" (Københavns Universitet) lavede i 2007:

§ 3. God videnskabelig praksis kræver hensyntagen til bl.a.:

forskningens uafhængighed og forskernes ytringsfrihed som nærmere anført nedenfor stk. 3, 
Stk. 3. Universitetet skal værne om sin forskningsfrihed og søge højeste niveau af videnskabelig standard og etik. Forskningsfrihed indebærer frihed til at vælge forskningsemne, frihed til at stille spørgsmål, frihed til at bestemme hvilket materiale og hvilke metoder man vil benytte for at finde svar, og frihed til at fremlægge hypoteser, resultater og ræsonnementer offentligt (Københavns Universitets regler om god videnskabelig praksis 2007, min fremhævning).

Disse formuleringer i universitetets interne regler svarer helt til, hvad man internationalt definerer som forskningsfrihed. Jeg var med til at formulere disse sætninger i 2007 som medlem af Praksisudvalget på Københavns Universitet, og de er nogenlunde direkte skrevet af efter ordlyden i en meget grundig norsk udredning om akademisk frihed fra 2006 (Norges offentlige utredninger 2006). De udtrykker universitetets officielle regler.

Normalt har man betragtet censur og indblanding fra politiske eller religiøse autoriteter som noget, der hører til i totalitære regimer, men ikke i moderne demokratiske og pluralistiske samfund. Det er desværre nok for blåøjet. Det vil jeg belyse med nogle eksempler, der har det til fælles, at forskningen flettes ind politiske og/eller økonomiske interesser. ${ }^{2}$

\section{Det Økonomiske Råd}

Det første eksempel vedrører Det Økonomiske Råd. Det hører ikke under universiteterne, men rådets sekretariat udfører forskning (med en årlig bevilling på ca. 30 mil.) og ledes af - nu - fire økonomer, som er forskere, typisk universitetsprofessorer. Jeg vil se på, hvordan mulighederne er for frit at udtrykke uenigheder der.

Først selve institutionen. Den blev oprettet i 1962 efter forslag fra den radikale handelsminister Kjeld Philip med det formål, som er angivet her:

$\S 1$. Der oprettes et økonomiske råd, hvis opgave er at følge landets økonomiske udvikling og belyse de langsigtede udviklingsperspektiver samt at bidrage til at samordne de forskellige økonomiske interesser (Det Økonomiske Råd 2013).

Som bekendt består rådet ud over formandskabet af et antal medlemmer, der repræsenterer samfundets magtcentre - statsapparat, nationalbank og de vigtigste interesse- og arbejdsmarkedsorganisationer. Formandskabet udpeges formelt af ministeren, men i praksis via selvsupplering.

Specielt ved den danske ordning er dels sammenblandingen af ekspertrolle og politisk rolle, som fremgår af formålsparagraffen, og dels, svarende hertil, indlejringen af ekspertfunktionen i et råd af repræsentanter for politisk og økonomisk magt. Lad os se, om det kan have konsekvenser for eksperternes ytringsfrihed. 
Her kan vi tage udgangspunkt i formandsskabets såkaldt "uskrevne regler". Uanset benævnelsen er de omhyggeligt skrevet ned:

DØR: "Uskrevne regler for formandsskabets virke" (fra 3.10.1991)

1. Medlemmerne af formandskabet er uafhængige af eksterne interesser og derfor uafhængige af erhvervsvirksomheder samt af erhvervslivets og arbejdsmarkedets organisationer.

2. Medlemmer af formandskabet gennemdiskuterer foruden rapporter til rådet bl.a. i samme forbindelse grundlaget for deres deltagelse i den offentlige debat med henblik på at samordne synspunkter om emner, som er centrale for rådets arbejde.

3. Medlemmer af formandskabet undlader i en periode af to måneder før et rådsmøde offentligt at kommentere emner, som behandles i en kommende rapport, med mindre der i formandskabet er enighed om, at der foreligger en tvingende grund til at fravige dette (personlig mail fra sekretariatschef John Smidt, 7. sept. 2012).

Reglerne blev nedskrevet i 1991, og de slår først fast, at formandsskabet er uafhængigt af eksterne interesser. Dernæst følger to regler, der begge må siges at begrænse medlemmernes ytringsfrihed og mulighed for deltagelse i offentlig debat ganske betragteligt. Pkt. 2 omtales som "konsensusklausulen" og siger, at formændene skal "samordne" deres synspunkter. Pkt. 3 fastsætter en spærretid på to måneder for hver rapport, der udsendes. Da der udsendes tre rapporter årligt, betyder det, at vismændene halvdelen af året ikke må udtale sig. Det er klart, at begge punkter er i klar modstrid med de offentlighedsprincipper, der gælder for forskning. Dertil kommer et princip, som ikke står i reglerne, men som har været gældende, nemlig at man ikke bruger mindretalsudtalelser i rapporterne (se Kærgård 1996 og 2003 for omtale af reglerne og deres begrundelse).

Punkt 1 skulle i virkeligheden nok være formuleret lidt anderledes, nemlig således: "fra nu af vil formandskabet prøve at blive mere uafhængige ...". Baggrunden var nemlig en bestemt hændelse i 1991. Der skete det - åbenbart uhørt provokerende - at en enkelt vismand på egne vegne offentligt fremsatte et forslag, nemlig professor på Handelshøjskolen i København Niels Blomgren Hansen i en kronik i Weekendavisen. Forslaget stødte an mod magtfulde interesser, og et andet medlem af rådet, LO-formand Finn Thorgrimson, for $\mathrm{i}$ harnisk. Han forlangte Blomgren sat på plads.

$\mathrm{Nu}$ kunne man forestille sig, at overvismanden og hans kolleger ville stå frem og forklare Thorgrimson, at alle selvfølgelig havde lov til at fremsætte alle de forslag og synspunkter, de måtte have, til gavn for en åben demokratisk debat. Det skete imidlertid ikke. Tværtimod, resultatet blev som beskrevet her af Tøger Seidenfaden i en leder i Weekendavisen: 
Professor Blomgren-Hansen, medlem af Det økonomiske Råds formandskab, foreslog sidste fredag her i avisen, at man gjorde noget ved arbejdsløsheden. Det fik LO til at sammenkalde Det økonomiske Råd med det ene formål at banke professoren på plads, mens hans kollega og overvismand, professor Claus Vastrup, der ellers også har sine meningers mod, slet og ret krævede hans afgang (Seidenfaden 1991).

Efterfølgende kastede et kor af forhenværende vismænd og repræsentanter fra arbejdsmarkedsorganisationer, Industrirådet, Finansministeriet, Danmarks Statistik m.fl. sig over Blomgren og krævede hans afgang. Det, der manglede, var imidlertid en klar begrundelse for, hvad galt der var i at enkelte medlemmer af formandsskabet ytrede sig med egne synspunkter. Det argument kom ærkevismanden Anders Ølgaard med i et indlæg, som jeg så valgte at kommentere i Politiken:

Baggrunden var og er [skrev Ølgaard], at de fleste trækker på smilebåndet ad økonomer, for "de kan jo alligevel ikke enes om noget som helst". For at undgå "den slags nedladende bemærkninger", har vismændene altid undgået mindretalsudtalelser i deres rapporter (Andersen 1991a).

En anden forklaring på lukketheden og konsensusklausulen kunne være sammenblandingen af ekspertrolle og politisk rolle. Hvis man forestiller sig, at vismændene mødte frem til et rådsmåde med en rapport, hvor de sagde: "vi er rygende uenige om, hvordan det vil gå, hvis vi fx sætter mindstelønnen ned, men nu skal vi samordne jeres interesser", så er det tænkeligt, at opgaven blev vanskeligere, end hvis de tilslørede deres uenighed. Det problem trak jeg frem i et andet indlæg i Handelshøjskolens blad, hvor jeg modstillede vismændenes munkedisciplin med Mertons princip om organiseret skepticisme.

\section{Munkedisciplin eller organiseret skepticisme?}

Tilbage står derfor, at forløbet har afsløret meget alvorlige problemer i forholdet mellem forskerrolle, offentlighed og eksterne brugere af ekspertise på universiteter og læreanstalter. På grund af den særprægede sammenblanding af ekspertfunktion og politisk funktion, som er nærmest officielt institutionaliseret i Det Økonomiske Råd og Vismandsinstitutionen, bliver problemet særligt synligt her (Andersen 1991b).

Mit synspunkt var og er, at det tværtimod er en pligt at lade uenigheder komme frem. Argumentet vandt dog ikke genklang. Resultatet blev, at Blomgren blev presset til at forlade sin post, og at formandskabet altså i stedet kodificerede de nævnte regler. Det basale problem er, at faglige oplysninger og vurderinger kun kommer frem i gradbøjet og filtreret form. Det skader forskningen, rådgivningen og demokratiet. 
Mange husker, at der for et par år siden var en sag efter et alvorligt jordskælv i Italien. Ca. 300 mennesker omkom, og der var store materielle skader. Godt et år efter blev syv eksperter, der stod for varslingstjenesten, idømt seks års fængsel for på et offentligt møde at have varslet forkert ved at sige, at der ikke ville komme noget jordskælv. De blev dømt for dermed at gøre sig skyldige i manddrab. Bemærk, at de ikke blev dømt for ikke have forudsagt skælvet. Hvis de havde sagt, at de ikke kunne vide noget, var de ikke blevet dømt.

Forestil jer nu, at det der skete var følgende: de syv seismologer sad og granskede deres grafer og data, for at vurdere jordskælvsfaren. Det viste sig, at de ikke kunne blive enige. Da de nødigt ville udsættes for nedladende bemærkninger og at folk skulle trække på smilebåndet ad dem, aftalte de at fremlægge flertalssynspunktet som det, gruppen var enige om. Afstemningen endte fire - tre for synspunktet, at der ikke kom noget jordskælv. De går ud og meddeler, at de i enighed vurderer, at der ikke kommer noget jordskælv. Folk går beroligede hjem og hygger sig med deres rødvin. Skælvet kommer, og 300 mennesker bliver slået ihjel. Mange vil vel nok sige, at det var fortjent, at eksperterne kom bag tremmer. Havde de sagt, at tre ud af de syv mente, at der godt kunne komme et jordskælv, ville myndighederne nok have beordret evakuering.

Hvad er den principielle forskel til økonomiske og andre analyser, prognoser og vurderinger? Beslutninger på et forkert grundlag kan koste uskyldige mennesker jobbet, virksomheder kan gå konkurs, folk kan blive sat på gaden eller miste deres opsparing. Det er klart, at det gør en forskel, om en analyse eller vurdering fremsættes, som noget eksperterne er enige om, eller som noget de er rygende uenige om. Ansvarlige politikere og alle andre, der måtte bruge analyserne som vejledning for beslutninger, vil selvfølgelig beslutte anderledes, hvis en prognose, fx om virkninger af at sænke minimallønnen, virker meget usikker, end hvis den virker sikker.

I den tyske lov om deres økonomiske råd fra 1963 står i § 3, at mindretalsvurderinger skal komme til udtryk. I den tilsvarende svenske lov fra 2007 står i § 12, at eventuelt afvigende meninger skal fremgå (Wren-Lewis 2013). I 2009 udsendte rektorkollegiet en hvidbog om forskningsbaseret myndighedsbetjening, hvor de side 14 skriver, at "de pågældende forskere må kunne redegøre for, hvor langt enigheden rækker" (Danske Universiteter 2009). Det skal de gøre af hensyn til myndighederne. Men vismændene holder indtil videre fast i munkedisciplinen. Synspunkter, der strider mod flertalsortodoksien, har trange kår.

Konsensuskulturen forstærkes yderligere af, at formandsskabet er selvsupplerende. Det vil altid medføre risiko for indavl, konformisme og sektdannelse. Det er nærliggende at antage, at økonomer, der endnu ikke har været vismænd, men gerne vil være det, vil være meget forsigtige med at udtale sig i modstrid med, hvad de siddende vismænd mener. Risikoen er overhængende for, at debatten foregår i et ekkorum, hvor man hører det, man selv råber, og 
tror det kommer fra fjerne egne. Videnskabsetik, professionsetik og hensyn til demokratisk debat gør det uforståeligt, at man opretholder sådan en ordning.

\section{Burkarapporten}

Sagen dukkede frem ved, at der i januar 2010 opstod en ophedet debat om resultater fra en hemmelig rapport, udarbejdet ved Københavns Universitet. Rapporten handlede om udbredelsen af brug af burkaer i Danmark, og dens resultater og metoder blev heftigt angrebet, bl.a. af folketingsmedlemmer (Naser Khader m.fl.). Debatten foregik på grundlag af oplysninger, som var lækket til et enkelt dagblad, og ingen andre kunne få rapporten.

Forskere bag rapporten blev heftigt angrebet for brug af dårlige metoder, utroværdighed mv., men de forblev tavse. Årsagen hertil kom først frem efter en uges tid. Den blev afsløret af dekanen på Det humanistiske Fakultet:

Lukketheden omfatter dog også Københavns Universitet. Her afviser dekan Kirsten Refsing således også at give Ritzau aktindsigt i undersøgelsen, som blev sendt til burkaudvalget før jul. Det har hun nemlig lovet. "Vi har sådan en hemmelighedsklausul og har lovet at holde den fortrolig, indtil arbejdet er færdigt i udvalget. Det står i den kontrakt, vi har skrevet under på”, siger hun (Ritzau 12.1. 2010).

Det viste sig, at rapporten var bestilt af et "Tværministerielt hurtigt arbejdende embedsmandsudvalg", der var nedsat august 2009. "Hemmelighedsklausulen" står ganske rigtigt klart formuleret i kontrakten og ser således ud:

Indenrigs- og Socialministeriet fastlægger rammerne for rapportens offentliggørelse. Leverandøren må undervejs i arbejdet ikke offentliggøre eller offentligt omtale delresultater mv. (Kontrakt, underskrevet af institutleder). ${ }^{3}$

Der er tale om en klausul, som ikke blot strider mod de forskningsetiske regler (citeret ovenfor), men også imod lov om offentlighed i forvaltningen, ifølge pressejuristen Oluf Jørgensen. Fordi to parter aftaler, at de vil bryde loven, bliver det ikke af den grund lovligt. Det endte selvfølgelig også med, at rapporten blev udleveret.

Universitetsloven angiver helt klart, hvor ansvaret for overholdelse af bestemmelsen om, at universitetet skal værne om videnskabsetik, ligger, nemlig hos ledelsen. I det foreliggende tilfælde ser vi, at en institutleder skriver under på en kontrakt, som åbenlyst strider mod forskningsetik, og at dekanen bakker det op. Hverken i den debat, jeg forsøgte at rejse i Universitetsavisen (Andersen 2010), eller andre steder, kom der nogen klar tilkendegivelse fra ansvarlige ledere om, at man ikke burde have skrevet under på kontrakten. Formanden for Praksisudvalget blev spurgt og svarede, at han kun kendte 
sagen af omtale, men at han nok mente, at formuleringen burde have været "lidt anderledes", især at der burde være en tidsbegrænsning på hemmeligholdelse. Han fandt det åbenbart ikke nødvendigt at sætte sig nøjere ind i sagen. Jeg var på det tidspunkt gået ud af Praksisudvalget, men jeg mener klart, at udvalget burde have taget stilling og meldt ud, hvad god praksis skal være for universitetets ledelse og forskere i relation til kontrakter med hemmelighedsklausuler. Til forskernes ære tjener, at de i hvert fald ikke lod deres resultater påvirke.

Sagen viser, at vores tillid til, at ledelsen vil vogte over publiceringsfriheden, bør være meget begrænset. Efter Penkowa-sagen blev det besluttet at indføre kurser i forskningsetik for ph.d.-studerende. Meget tyder på, at man skulle starte fra toppen, med rektorer, dekaner og institutledere.

\section{Censursagen fra Aarhus Universitet}

Det tredje eksempel er interessant, fordi det vedrører ytringsfrihed på et tidligere sektorforskningsinstitut. I 2007 blev en række sektorforskningsinstitutter indfusioneret på universiteterne, og i samme omgang blev universitetsloven ændret, så universiteterne kunne pålægges at udføre myndighedsopgaver, dvs. den slags forskning som før lå på sektorforskningsinstitutter. Det er klart, at politiske myndigheder skal kunne få udført forskningsopgaver, men mange så en risiko for, at det ville kunne begrænse universiteternes forskningsfrihed, når ministeriet nu fik beføjelser til at pålægge universiteterne bestemte politisk definerede opgaver, som før lå på sektorforskningsinstitutter. Et modsatrettet argument var imidlertid, at det omvendt ville være en fordel, at sektorforskere nu ville få samme frihedsgrader som universitetsforskere.

Et af de sektorforskningsinstitutter, der blev indfusioneret på Aarhus Universitet, var Danmarks Miljøundersøgelser, DMU. Det eksempel jeg vil omtale, blev i pressen benævnt "Censursagen på AU". Censuren drejede sig her ikke om bestemte forskningsresultater, men om forskeres ret til at ytre sig om forhold vedrørende forskningsinstitutionens forbindelse til eksterne interesser, i dette tilfælde en privat virksomhed.

Forløbet var i korte træk, at der i 2008 dukkede en sag op i pressen, som drejede sig om, at Cheminova solgte en meget farlig plantegift, Methyl parathion, i Brasilien. Giften er forbudt i Europa, og nu var der optræk til, at den også ville blive forbudt i Brasilien. Cheminova var i gang med at afværge forbuddet via domstolene, og der opstod en offentlig debat om sagen.

$\mathrm{Nu}$ kunne man forestille sig, at forskerne på DMU som de førende eksperter i landet stillede sig til rådighed for offentligheden med oplysninger, fx om hvor farligt stoffet var, og hvorfor det var blevet forbudt i Danmark og EU, om der er tungtvejende grunde til alligevel at bruge det i Brasilien osv. Hvis ikke de gjorde det af egen drift, kunne man formode, at chefen ville gå en tur ned ad gangen og råbe ind på kontorene: "Så er det med at komme ud og deltage i debatten, venner", jf. $\S 2$, stk. 3 i universitetsloven. 
Men forskerne hørte vi ikke. I stedet hørte vi rektor for Aarhus Universitet Lauritz Holm, der som rektor også er øverste chef for DMU. Han satte tingene klart på plads ved at slå fast: "Universitetet har tiltro til, at kemikoncernen har moralen i orden i Brasilien" (Ritzau 18.08.2008).

Når Lauritz Holm udtaler sig her, er det dog ikke kun som øverste chef for AU og DMU, selvom han formulerer sig sådan. Han kunne også have sagt: "Som hovedaktionær i Cheminova kan jeg slå fast, at Aarhus Universitet, herunder DMU, har tiltro til, at kemikoncernen har moralen i orden i Brasilien". Cheminova ejes af Aarhus Universitetsfond, der igen ledes af repræsentanter for ledelsen på Aarhus Universitet. Lauritz Holm er født medlem og formand for fondens bestyrelse. Han er altså bestyrelsesformand for den koncern, der styrer Cheminova. Fondens indtægter er i høj grad påvirket af Cheminovas resultater, og ifølge fundatsen skal fondens midler udelukkende anvendes til støtte af forskning på Aarhus Universitet (Aarhus Universitets forskningsfond 2013). Det betyder, at Aarhus Universitet får flere penge til rådighed, hvis det går godt for Cheminova. Omvendt, hvis salget og aktieværdien falder, vil der være færre penge til rådighed til forskningen på Aarhus Universitet.

Man kunne tænke sig, at denne simple sammenhæng påvirker, hvordan Lauritz Holm udtaler sig, når det sker som chef for Aarhus Universitet og DMU. Man kunne også tænke sig, at det påvirker universitetets lyst til at kaste sig over miljøforskning og at bidrage med debatindlæg, der kunne svække kursværdien af Cheminova-aktier. Man har ved indfusioneringen med åbne øjne sat miljøforskningen i denne groteske interessekonflikt.

At det imidlertid også på en meget håndfast måde afskærer forskerne på DMU for overhovedet at rejse en debat om disse problemer ikke bare offentligt, men også internt blev demonstreret klart, da en af forskerne gjorde forsøget. Kort fortalt var forløbet, at seniorforsker på DMU Mette Jensen på intern mail forsøgte at indsamle synspunkter fra forskerkolleger. Det fremkaldte trusler om disciplinære sanktioner fra ledelsen. I stedet for at lukke munden valgte forskeren imidlertid at udvide debatten til et bredere forum med et indlæg i universitetets blad.

Reaktionen kom prompte: universitetet iværksatte en fyringssag. Så let var det dog trods alt ikke. Faktisk har også offentligt ansatte ytringsfrihed i hvert fald formelt, og efter intervention fra fagforeningen DJØF måtte universitetet trække fyringen tilbage. Desværre fulgte forløbet derefter et kendt mønster: det viste sig, at arbejdsforholdene efterfølgende blev så besværlige og utilfredsstillende, at Mette Jensen foretrak at forlade sin stilling på DMU.

Det er jo ikke første gang, vi har set, at garantierne for offentligt ansattes ytringsfrihed, som på papiret er ganske vidtgående, ikke er meget værd i praksis. Forskere, der vil bruge deres ytringsfrihed om ubehagelige sager i offentlighedens interesse, risikerer at skulle gå planken ud, selvom de har ret.

En debat om universitetets bindinger til Cheminova kom aldrig. Det kunne ellers være tiltrængt. Giftstoffet produceres og sælges stadig. Nu vist nok 
i kapsler. Jeg kunne godt tænke mig at vide, om stoffet er mindre farligt i kapsler. Men det nytter nok ikke at spørge forskerne på Århus Universitet og DMU. De risikerer åbenbart jobbet, hvis de udtaler sig.

\section{Projekt for Forsknings- og Innovationsstyrelsen}

Det sidste eksempel er en hemmeligholdelsesklausul, som jeg selv har været forsøgt pålagt. Det drejer sig om et projekt, jeg lavede sammen med Inge Henningsen i 2008/09, nemlig en rapport, som vi blev bedt om at lave til Forsknings- og Innovationsstyrelsen (FI). Rapporten skulle fremlægges på Eliteforsk-konferencen, den ceremonielle konference, hvor der under højtidelige former og med kongelig medvirken uddeles de årlige priser til eliteforskere. Vi aftalte, at rapporten skulle handle om "mangfoldighed og universalisme" i forskningsrådenes fordeling af midler. Nærmere bestemt skulle vi se på, hvordan ansøgernes sociale baggrund, deres køn samt deres nationale oprindelse spillede ind på chancerne for at få midler i forskningsrådene (Andersen og Henningsen 2009).

Overraskelsen kom, da vi fik kontraktudkastet. På det tidspunkt var vi faktisk gået i gang med projektet, men da vi så kontraktudkastet, var vi indstillede på at stoppe med det samme. Specielt med hensyn til publiceringsfrihed var det, jeg blev bedt om at underskrive, følgende:

Kunden erhverver ejendomsret, ophavsret og enhver anden rettighed til alle dokumenter, som Konsulenten udarbejder i forbindelse med opgavens udførelse, herunder rapporter samt data, som Konsulenten frembringer som led i kontrakten. Konsulenten og dennes personale skal iagttage ubetinget tavshed med hensyn til oplysninger vedrørende Kundens eller andres forhold, som der opnås kendskab til i forbindelse med opfyldelse af denne kontrakt.

Jeg er konsulenten, og kunden er FI. Man skal være opmærksom på, at FI er den administrative myndighed, hvorunder bl.a. Det Frie Forskningsråd hører. Jeg sad selv på det tidspunkt i forskningsrådet, og der har vi helt klare regler om, at resultater skal publiceres uden bindinger, og at der skal være fri adgang for andre forskere til data, når resultaterne publiceres, så der er mulighed for at kontrollere resultaterne. Hvis de forudsætninger ikke er opfyldt, kan ansøgere ikke få penge. Så jeg blev altså af den myndighed, der administrerer forskningsrådene, bedt om skrive under på noget, som jeg ville betragte som begrundelse for afvisning af en ansøgning til forskningsrådet. Yderligere forbløffet blev vi, da vi fik at vide, at der var tale om en kontrakt, som FI normalt anvendte ved den slags projekter (og som fortsat anvendes). ${ }^{4}$

Som sagt var vi parat til at droppe projektet, men det viste sig, at FI meget gerne ville have løst opgaven, så det endte med, at vi fik en anden kontrakt uden begrænsninger af publiceringsfriheden. 
Det er lidt gådefuldt, hvorfor FI bruger den slags kontrakter. En grund kunne være den, som Max Weber formulerer så rammende, at det simpelthen ligger i embedsapparatets natur, at man helst skal sikre sig mulighed for hemmeligholdelse, hvis det overhovedet kan lade sig gøre:

Begrebet embedshemmelighed er bureaukratiets specifikke opfindelse; og intet forsvares af bureaukratiet med en sådan fanatisme som netop denne indstilling (Max Weber 2003:101, skrevet 1910/13).

At han har fat i noget, der stadig gælder, ser man også af centraladministrationens vedholdende pres i forbindelse med den revision af offentlighedsloven, som blev gennemført sommeren 2013. En anden mulighed kunne selvfølgelig være, at embedsmændene ville sikre sig mod, at vi skrev noget, der kunne være politisk ubekvemt for deres minister, der den gang hed Helge Sander. I hvert fald var det både direktøren og kontorchefen magtpåliggende, at de fik lov at se rapporten, før den gik i trykken. Det kunne vi selvfølgelig ikke have noget imod - alle og enhver kunne få lov at se den, før den blev trykt.

Eksemplet viser altså, at den offentlige myndighed, som er administrativt ansvarlig for bl.a. Det Frie Forskningsråd, og som man kunne tro var en af de første til at holde øje med, om universitetslovens $\S 2$ om forskningsfrihed overholdes, tilsyneladende rutinemæssigt pålægger kontraktpartnere i forskningen begrænsninger, som er i lodret modstrid med etiske principper for fri forskning. Det er næppe der, vi kan forvente at finde de mest nidkære og ihærdige forkæmpere for forsknings- og publiceringsfrihed. Retfærdigvis skal det siges, at embedsapparatet aldrig har forsøgt at påvirke forskningsrådets faglige vurderinger, mens jeg var med.

Det er selvsagt af stor betydning for tilliden at finde ud af, hvor udbredt dette hemmelighedskræmmeri er.

\section{Konklusion}

Konklusionen er nedslående. Den frihed, som Charles II i 1663 gav til Robert Boyle og andre medlemmer af Royal Society, er ved at blive undermineret af Forskningsstyrelsen, rektorer, dekaner, institutledere og økonomiske vismænd. De eksempler, jeg har trukket frem, er jo kun nogle af dem, vi kender - tænk på Penkowa-sagen, Koldau-sagen og sagen om beskæftigelsesministeriets intervention i SFI's evalueringsrapport vedrørende 300-timersreglen, som journalisten Jesper Tynell afdækkede, ${ }^{5}$ og der er uden tvivl et meget stort mørketal. Ingen høster hæder og ære ved at gå ud og fortælle, at de har skrevet under på hemmelighedsklausuler. Eksemplerne viser, at truslerne kommer fra toppen - ledelsen og det politiske niveau. Det er dem, der har magten til at begrænse ytringsfriheden, og i det eksisterende topstyrede system skal topledelsen hverken stå til ansvar opad eller nedad. Der findes også begrænsninger i form af selvcensur og kollegial konformisme, men det udspringer hovedsageligt af pres fra magt- og pengeregimerne (finansieringsmuligheder). 
Ud over de mekanismer, som de her valgte eksempler illustrerer, er der jo andre, som virker måske med større styrke. Først og fremmest i forhold til forskning med kommercielle potentialer, hvor patentbeskyttelse afleder hemmeligholdelsesklausuler, som er undtaget de normale forskningsetiske regler om publicering. Dertil kommer hele det grå område med begrænsninger i form af selvcensur som følge af usikkerhed om ansættelses- og karriereforhold. I den forbindelse er den udstrakte praksis med eksternt finansieret tidsbegrænset ansættelse en faretruende tendens. Vi har ingen helt dækkende statistik, men i hvert fald over halvdelen af universiteternes forskere er ansat på korttidskontrakter få år ad gangen. Når kontrakten udløber, er de ikke ansat længere og skal finde en ny kontrakt. Det er klart, at det begrænser mulighederne for uafhængig forskning og specielt forskning, som kan være kontroversiel.

Vi ser frem til den dag, hvor dette system breder sig til domstolene. Hvorfor skal skatteyderne betale? Dommerne vil næppe have besvær med at finde pengestærke sponsorer, der kan betale for at få sager afgjort, både løn og udgifter til leje af retslokaler mv. Systemet med brugerbetalt rettergang er jo også allerede afprøvet i andre lande.

Forskningsinstitutionerne er på vej til at blive underordnet statsforvaltning og pengeregimet. Den aktuelle ændring af Lov om offentlighed i forvaltningen vil yderligere begrænse adgang til data og resultater fra universiteter og sektorforskning, som skal bruges af politikere. Tidligere direktør i forskningsstyrelsen og ved GEUS, Jens Morten Hansen, har kaldt udviklingen "syg" (P1 morgen, d. 10.5.2013). "Det er uholdbart og udemokratisk, for det åbner ukontrollerbare muligheder for politiseret faktafordrejning og dermed magtmisbrug" (Hansen 2013).

Der er ingen tegn på, at ansvarlige politikere vil ændre kursen, snarere tværtimod. Det, vi forskere kan gøre, er for det første at lade vore uenigheder komme til udtryk og at gå åbent ud med kritik særligt mod skråsikkerhed og ortodoksi. Og for det andet at skærpe opmærksomheden mod de begrænsninger af forskningsfriheden, der kommer udefra, sige fra og skaffe dokumentation og analyser om udbredelsen og konsekvenserne. 


\section{Noter}

Artiklen er en forkortet og bearbejdet version af min fratrædelsesforelæsning, Sociologisk Institut, Københavns Universitet d. 17. maj 2013.

1. Kilde til figurerne 1, 2 og 4: Andersen 1998:37 (tabel 10, bearbejdet).

2. Nøglepersoner vedrørende de enkelte eksempler har haft mulighed for at faktachecke og kommentere fremstillingen.

3. Institutlederen nægtede at udlevere kontrakten, da jeg med henvisning til Lov om offentlighed i forvaltningen anmodede om det. Jeg fik den senere ved henvendelse til Indenrigsministeriet.

4. Personlig mail fra direktør Hans Müller Pedersen, Styrelsen for Forskning og Innovation, af 16. maj 2013.

5. Tynell afslørede endnu et eksempel i DR-programmet Orientering, d. 15. august 2013, nemlig om hvordan Naturstyrelsen forlangte dele af konklusionerne fjernet i et notat, skrevet af forskere fra Aarhus Universitet.

\section{Litteratur}

Andersen, Heine 1991a: "Kom dog frem med uenigheden". Politiken, 24.10.1991.

Andersen, Heine 1991b: "Munkedisciplin eller organiseret skepticisme". Kræmmerhuset. November 1991.

Andersen, Heine 1997: Forskere i Danmark - videnskabssyn, vurderinger og aktiviteter. Københavns Universitet, Sociologisk Institut.

Andersen, Heine 1998: Politiske holdninger og faglige overbevisninger blandt samfundsforskere $i$ Danmark. Sociologisk Rapportserie, nr. 6. Københavns Universitet, Sociologisk Institut.

Andersen, Heine 1999: "Political Attitudes and Cognitive Convictions among Danish Social Science Researchers". Scientometrics, vol. 46, no. 1, 1999:87-108.

Andersen, Heine 2003: Samfundsvidenskaber i kontekst. Frederiksberg: Roskilde Universitetsforlag.

Andersen, Heine 2010: "Burkaundersøgelsen: værner universitetet om god videnskabelig praksis?" Universitetsavisen, nr. 2, februar 2010.

Andersen, Heine \& Inge Henningsen 2009: Forskningsråd i Danmark. Mangfoldighed og universalisme. København: Sociologisk Institut.

Bredsdorff, Nils 2009: "Kritikkens nødvendighed eller det venligt fjendtlige samarbejde mellem forskerne". Dansk Sociologi, nr. 4/19. årg., 2009:49-69.

Danske Universiteter 2009: Danske Universiteters hoidbog om forskningsbaseret myndighedsbetjening. København: Danske Universiteter.

Det Økonomiske Råd 2013: http://www.dors.dk/sw6258.asp.

Expert Panel, University of Chicago 2013: http://www.igmchicago.org/igm-economicexperts-panel/poll-results?SurveyID=SV_br0IEq5a9E77NMV.

Hansen, Jens Morten 2013: "Sektorforskning udsat for faktafordrejning". Forskerforum (interview). 30. 4. 2013.

Kærgård, Niels 1996: "Økonomiske vismænd - politiserende økonomer eller objektive eksperter". Nationaløkonomisk Tidsskrift, vol. 134, 1996:113-128.

Kærgård, Niels 2003: "Videnskab og politik". Nationaløkonomisk Tidsskrift, vol. 141, 2003:399-408. 
Københavns Universitets regler om god videnskabelig praksis 2007: http://praksisudvalget. ku.dk/regler_vejl/pu_regler.pdf.

Merton, Robert K. [1942] 1969: "Science and Democratic Social Structure", i Social Theory and Social Structure. New York: The Free Press, p. 604-615.

Myrdal, Gunnar 1968: Objektivitetsproblemet $i$ samhällforskningen. Stockholm: Rabén \& Sjögren.

Norges Offentlige Utredninger 2006: Akademisk frihet. Oslo: Utdannings- og forskningsdepartementet.

Popper, Karl R. 1962: "Die Logik der Sozialwissenschaften". Kölner Zeitschrift für Soziologie und Sozialpsychologie, vol. 14, nr. 2, 1962:233-248.

Royal Society of London 2013: http://royalsociety.org/about-us.

Seidenfaden, Tøger 1991: "Et samfundsproblem". Weekendavisen, d. 4.10.1991:8.

Weber, Max 2003: Udvalgte tekster, bd. 2. København: Hans Reitzels Forlag.

Wren-Lewis, Simon 2013: Fiscal Councils. International examples. https://sites.google. com/site/sjqwrenlewis/fiscal-councils/international-examples.

Aarhus Universitets Forskningsfond 2013: Fundats. http://auff.au.dk/fonden/fundats.

Heine Andersen

E-mail: ha@soc.ku.dk 